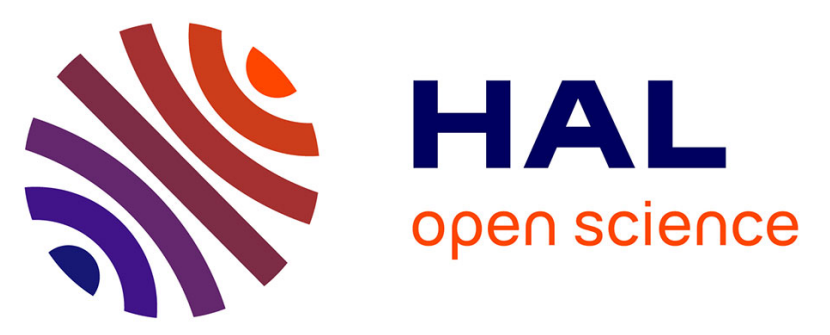

\title{
Pyrroloquinolone A, a new alkaloid and other phytochemicals from Atractylis cancellata L. with antioxidant and anticholinesterase activities
}

Mohamed Ibrahim Badaoui, Abdulmagid Alabdul Magid, Mohammed

Benkhaled, Chawki Bensouici, Dominique Harakat, Laurence

Voutquenne-Nazabadioko, Hamada Haba

\section{To cite this version:}

Mohamed Ibrahim Badaoui, Abdulmagid Alabdul Magid, Mohammed Benkhaled, Chawki Bensouici, Dominique Harakat, et al.. Pyrroloquinolone A, a new alkaloid and other phytochemicals from Atractylis cancellata L. with antioxidant and anticholinesterase activities. Natural Product Research, 2019, pp.1-7. 10.1080/14786419.2019.1682575 . hal-02430930

\section{HAL Id: hal-02430930 \\ https://hal.univ-reims.fr/hal-02430930}

Submitted on 24 Sep 2021

HAL is a multi-disciplinary open access archive for the deposit and dissemination of scientific research documents, whether they are published or not. The documents may come from teaching and research institutions in France or abroad, or from public or private research centers.
L'archive ouverte pluridisciplinaire HAL, est destinée au dépôt et à la diffusion de documents scientifiques de niveau recherche, publiés ou non, émanant des établissements d'enseignement et de recherche français ou étrangers, des laboratoires publics ou privés. 
Pyrroloquinolone A, a new alkaloid and other phytochemicals from Atractylis cancellata $\mathbf{L}$. with antioxidant and anticholinesterase activities

Mohamed Ibrahim Badaoui ${ }^{\mathrm{a}}$, Abdulmagid Alabdul Magid ${ }^{\mathrm{b}}$, Mohammed

Benkhaled $^{\text {a }}$, Chawki Bensouicic ${ }^{\mathrm{c}}$, Dominique Harakat ${ }^{\mathrm{d}}$, Laurence VoutquenneNazabadioko ${ }^{\mathrm{b}}$, and Hamada Haba ${ }^{\mathrm{a}, *}$

${ }^{a}$ Laboratoire de Chimie et Chimie de l'Environnement (LCCE), Département de Chimie, Faculté des Sciences de la Matière, Université de Batna-1 05000, Algeria

${ }^{b}$ Equipe Chimie des Substances Naturelles, Institut de Chimie Moléculaire de Reims (ICMRUMR CNRS 7312), Campus Sciences, Bât. 18, BP 1039, 51687, Reims Cedex 2, France ${ }^{C}$ Centre de Recherche en Biotechnologie, Ali Mendjli, UV 03, BP E73, Constantine, Algeria. ${ }^{d}$ Service Commun d'Analyses, ICMR-UMR CNRS 7312, Bât. 18 B.P. 1039, 51687, Reims, Cedex 2, France

* Corresponding author: Hamada Haba Tel: +213 333190 15; Fax: +213 333190 15; E-mail address: haba.hamada@yahoo.fr; hamada.haba@univ-batna.dz 


\begin{abstract}
A new alkaloid pyrroloquinolone A (1), along with fifteen known compounds 2-16 were isolated from the petroleum ether, EtOAc and $n-\mathrm{BuOH}$ extracts of the whole plant Atractylis cancellata $\mathrm{L}$. Their structures were elucidated on the basis of extensive spectroscopic analysis including 1D- and 2D-NMR and HR-ESI-MS techniques. This is the first report of alkaloids in the genus Atractylis. Some of the isolated compounds and extracts were evaluated for their antioxidant potential (scavenging activity of DPPH and ABTS radicals, and reducing $\mathrm{Fe}^{+3}$ and $\mathrm{Cu}^{+2}$ power assays) and acetylcholinesterase and butyrylcholinesterase inhibitory activities. Compounds $\mathbf{8}$ and $\mathbf{1 1}$ showed good antioxidant capacity compared to ascorbic acid, BHA, and BHT used as standards, whereas compounds $\mathbf{1}$ and $\mathbf{2}$ exhibited good anticholinesterase activities compared to galantamine used as standard.
\end{abstract}

Keywords: Asteraceae, Atractylis cancellata L., Pyrroloquinolone A, NMR, Antioxidant activity, Anticholinesterase activity

\title{
1. Introduction
}

The Asteraceae family called also Compositae is the most diverse of all plant families, and it is growing in the entire globe except for Antarctica, with 24000-30000 species and 1600-1700 genera (Funk et al. 2005). The Atractylis genus belonging to this family is widespread in the Mediterranean area, including 16 species in North Africa due to its variable climate (arid, semi-arid, tropical and desert) (Chabani et al. 2013).

The Atractylis species are used in folk medicine against urinary retention, intestinal parasites and snakebite poisoning, and for their anti-inflammatory and antipyretic activities (Larrey and Pageaux, 1995, El Rhaffari and Zaid 2002, Daniele et al. 2005, Melakhessou et al. 2018). In addition, many studies have been reported for Atractylis plants, which allowed the identification of diterpenes, triterpenes, saponins and flavonoids (Sadek et al. 1998, Chabani et al. 2013, Chabani et al. 2016a, Chabani et al. 2016b). Atractylis cancellata L., used in folk medicine for the treatment of skin disorders (Bammou et al. 2015), is an herbaceous endemic plant; it grows in semi-arid zone of Mediterranean area (Quezel and Santa 1963).

In this paper, we report the isolation and structural elucidation of one new alkaloid type pyrroloquinolone A (1), together with fifteen known secondary compounds including one alkaloid 2, seven flavonoids 3-9, three phenolic acids 10-12, and four triterpenes 13-16. In addition, the antioxidant capacities of extracts (PE, EtOAc and $n-\mathrm{BuOH})$ and some phenolic 
compounds were measured using DPPH, ABTS, CUPRAC, and reducing power methods. Furthermore, the acetylcholinesterase and butyrylcholinesterase inhibitory activities of extracts and the alkaloids $\mathbf{1}$ and $\mathbf{2}$ were tested.

It is worth to note that this work represents the first phytochemical and biological investigations of A. cancellata and the first report of alkaloids in the genus Atractylis.

\section{Results and discussion}

\subsection{Chemical constituents}

The $70 \%$ ethanol extract of dried whole plant $A$. cancellata was partitioned by liquid/liquid chromatography into three extracts PE, EtOAc and $n-\mathrm{BuOH}$. Purification of the PE, and EtOAc soluble parts gave the known compounds 13-15, and 3-6 and 16, respectively. While, one new alkaloid 1, in addition of seven known compounds 2 and 7-12 were isolated from the $n$ - $\mathrm{BuOH}$ soluble part (Figure 1). Their structures were elucidated on the basis of 1D- and 2DNMR and HR-ESI-MS techniques, and comparison with data reported in the literature. The known compounds were elucidated as the alkaloid 4-methoxy-1-methyl-2-quinolone (2) (Nayar et al. 1971), the flavonoids chrysin (3) (Liu et al. 2010), apigenin (4) (Liu et al. 2010), tricine (5) (Ghasemi et al. 2018), quercetin (6) (Liu et al. 2010), quercetin 3-O- $\beta$-Dglucopyranoside (7) (Chang et al. 2009), isoorientin (8) (Chang et al. 2009), and diosmin (9) (Szeleszczuk et al. 2017), the phenolic acids 4- $O$-caffeoyl-2- $C$-methyl-D-threonic acid (10) (Chang et al. 2009), chlorogenic acid methyl ester (11) (Chang et al. 2009), and 5-Ocaffeoylshikimic acid (12) (Khaligh et al. 2016). Finally, the triterpenes lupeol (13) (Silva et al. 2017), and oleanolic acid (14) (Seebacher et al. 2003), were identified with $\beta$-sitosterol (15) (Chaturvedula et al. 2012), and $\beta$-sitosterol-3-O- $\beta$-D-glucoside (16) (Peshin and Kar, 2017).

\subsection{Structural elucidation of the new compound}

Compound 1 was isolated as a white amorphous powder. The positive HR-ESI-MS showed a molecular ion peak at $\mathrm{m} / z$ 198.0791 $[\mathrm{M}]^{+}$(calcd. $\mathrm{C}_{12} \mathrm{H}_{10} \mathrm{~N}_{2} \mathrm{O}, 198.0793$ ). The ${ }^{1} \mathrm{H}-\mathrm{NMR}$ spectrum of 1 showed a methyl group signal at $\delta_{\mathrm{H}} 4.02(3 \mathrm{H}, \mathrm{s})$ and six aromatic proton signals at $\delta_{\mathrm{H}} 7.12(1 \mathrm{H}, \mathrm{d}, J=3.1 \mathrm{~Hz}, \mathrm{H}-3), 7.46(1 \mathrm{H}, \mathrm{d}, J=3.1 \mathrm{~Hz}, \mathrm{H}-2), 7.61(1 \mathrm{H}, \mathrm{t}, J=7.6 \mathrm{~Hz}, \mathrm{H}-8)$, $7.75(1 \mathrm{H}$, ddd, $J=8.7,7.6,1.3 \mathrm{~Hz}, \mathrm{H}-7), 8.01(1 \mathrm{H}, \mathrm{d}, J=8.7 \mathrm{~Hz}, \mathrm{H}-6)$, and 8.24 (1H, brd, $J=8.0$

$\mathrm{Hz}, \mathrm{H}-9)$. According to the correlation observed in the ${ }^{1} \mathrm{H}-{ }^{1} \mathrm{H}-\mathrm{COSY}$ spectrum between protons $\mathrm{H}-3 / \mathrm{H}-2, \mathrm{H}-8 / \mathrm{H}-7, \mathrm{H}-8 / \mathrm{H}-9$, and $\mathrm{H}-7 / \mathrm{H}-6$, and their coupling constants, we assumed 
that the protons H-6, H-7, H-8 and H-9 belong to the same aromatic ring which is disubstituted in ortho position; and the two protons $\mathrm{H}-2$ and $\mathrm{H}-3$ belong to an another aromatic ring. The ${ }^{13} \mathrm{C}$-NMR spectrum showed signal at $\delta_{\mathrm{C}} 152.4$ corresponding to a quaternary carbon of an ester or an amid group. The other signals are in the aromatic area shifts $\left(\delta_{\mathrm{C}} 103.9,108.6\right.$, $115.1,116.9,121.5,124.9,125.1,129.0,134.8$, and 135.1), in addition to a signal at $\delta_{\mathrm{C}} 33.1$ attributed to a methyl group. The chemical shifts of the carbon and the protons signals $\left(\delta_{\mathrm{H}}\right.$ $\left.4.02 / \delta_{\mathrm{C}} 33.1\right)$ of this methyl group suggested it to be linked to a nitrogen atom. The HSQC spectrum allowed the assignment of the protons at $\delta_{\mathrm{H}} 7.12,7.46,7.61,7.75,8.01$, and 8.24 to their carbons at $\delta_{\mathrm{C}} 103.9$ (C-3), 125.1 (C-2), 124.9 (C-8), 129.0 (C-7), 116.9 (C-6), and 121.5 (C-9), respectively. The HMBC spectrum exhibited ${ }^{3} J_{H / C}$ correlation between the protons of the $N$-methyl group $\left(\delta_{\mathrm{H}} 4.02\right)$ and carbons C-6, C-6a (135.1 ppm), and C-4 (152.4 ppm) (Figure 2) indicating that the nitrogen is related to the aromatic ring by the bond $\mathrm{N}-(\mathrm{C}-6 \mathrm{a})$, and the function will be an amid. The two protons of the aromatic ring H-6 and H-8 showed ${ }^{3} J_{H / C}$ correlations with the quaternary carbon at $\delta_{\mathrm{C}} 115.1$, ascribable to C-9a. The HMBC spectrum exhibited also the correlations H-6/C-8, H-7/C-6a, H-7/C-9 and H-9/C-6a, H-6/C-9b (134.8 ppm), and H-9/C-9b (Figure 2). According to the HMBC correlations H-2/C-9b and H3/C-9b, the carbon chemical shifts of C-2 (125.1 ppm) and C-9b (121.5 ppm), and the molecular formula obtained by HR-ESI-MS spectrum $\left(\mathrm{C}_{12} \mathrm{H}_{10} \mathrm{~N}_{2} \mathrm{O}\right)$, the carbons C-2 and C-9b were proposed to be connected by a second nitrogen atom (C-9b-NH-C-2). The HMBC correlations H-3/C-3a (108.6 ppm), H-2/C-3a and H-2/C-4 confirmed that C-3 is connected to C-3a (Figure 2), and were included in a pyrrole ring.

According to these data, this compound is composed of benzene and pyrrole rings linked to a pyridine ring including the amide group, which lead us to the structure of pyrroloquinolone. Thus, compound 1 was elucidated as 5-methyl-4,5-dihydro- $1 H$-pyrrolo[3,2-c]quinolin-4-one, previously synthetized by Tim and Keith, 1997, and named pyrroloquinolone A. 

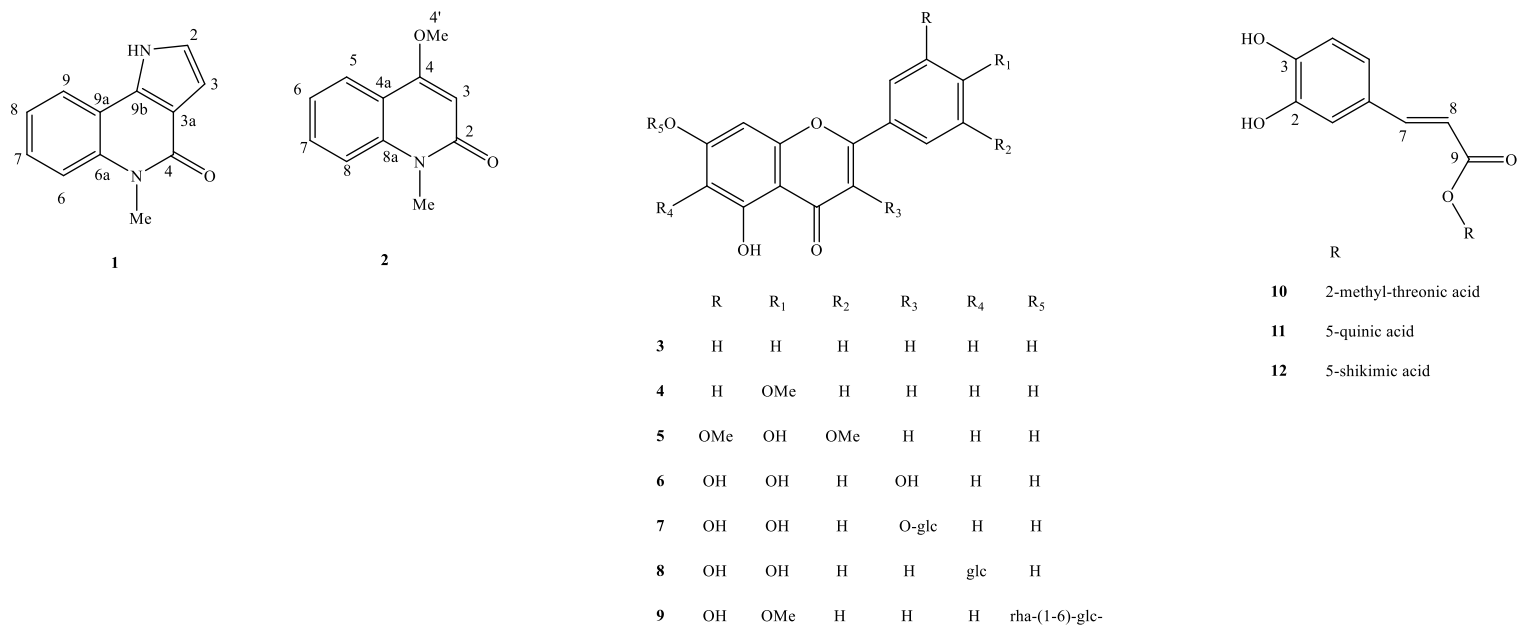

$10 \quad$ 2-methyl-threonic acid

$11 \quad 5$-quinic acid

$12 \quad 5$-shikimic acid
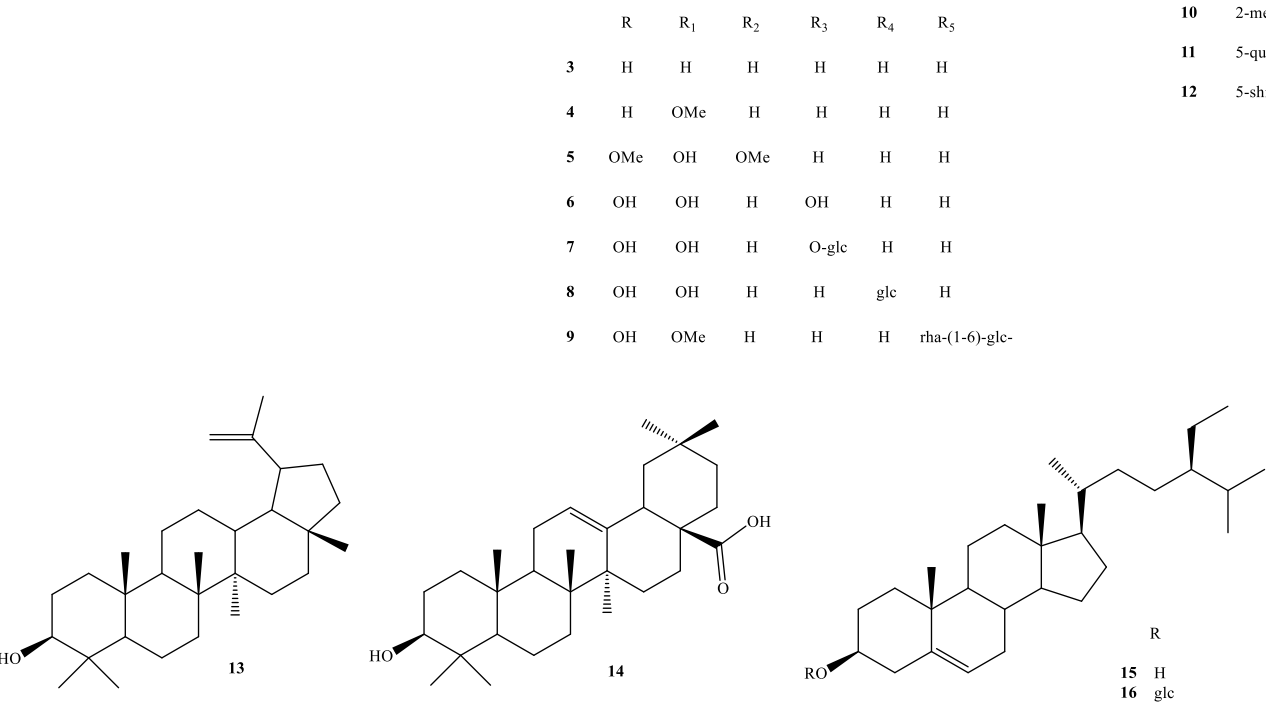

Figure 1. Chemical structures of compounds 1-16 isolated from A. cancellata L.

\subsection{Spectral data}

Pyrroloquinolone A (1): White amorphous powder; UV $\lambda_{\max }(\mathrm{MeOH}): 249,316,328 \mathrm{~nm} ;{ }^{1} \mathrm{H}$ NMR $\left(500 \mathrm{MHz}, \mathrm{CD}_{3} \mathrm{OD}\right): \delta_{\mathrm{H}} 4.02\left(3 \mathrm{H}, \mathrm{s}, \mathrm{N}-\mathrm{CH}_{3}\right), 7.12(1 \mathrm{H}, \mathrm{d}, J=3.1, \mathrm{H}-3), 7.46(1 \mathrm{H}, \mathrm{d}$, $J=3.1, \mathrm{H}-2), 7.61(1 \mathrm{H}, \mathrm{t}, J=7.6 \mathrm{~Hz}, \mathrm{H}-8), 7.75$ (1H, ddd, J=8.7, 7.6, $1.3 \mathrm{~Hz}, \mathrm{H}-7), 8.01$ (1H, d, $J=8.7 \mathrm{~Hz}, \mathrm{H}-6), 8.24(1 \mathrm{H}, \mathrm{brd}, J=8.0 \mathrm{~Hz}, \mathrm{H}-9) ;{ }^{13} \mathrm{C} \mathrm{NMR}\left(125 \mathrm{MHz}, \mathrm{CD}_{3} \mathrm{OD}\right) \delta_{\mathrm{C}} 33.1(\mathrm{~N}-$ $\mathrm{CH}_{3}$ ), 103.9 (C-3), 108.6 (C-3a), 115.1 (C-9a), 116.9 (C-6), 121.5 (C-9), 124.9 (C-8), 125.1 (C-2), 129.0 (C-7), 134.8 (C-9b), 135.1 (C-6a), 152.4 (C-4); HR-ESI-MS m/z 198.0791 [M] ${ }^{+}$ (calcd. $\mathrm{C}_{12} \mathrm{H}_{10} \mathrm{~N}_{2} \mathrm{O}, 198.0793$ ).

\subsection{Phenolic and flavonoid contents}

The total phenolic and flavonoid contents (TPC, TFC) were determined in the PE, EtOAc and $n$-BuOH extracts. The results were expressed by gallic acid equivalent as (mg GAE/g Extract) for TPC, and by quercetin equivalent as (mg QE/g Extract) for TFC. The $n$-BuOH extract showed the higher content of phenols $(53.20 \pm 1.21 \mathrm{mg}$ GAE/g) comparing to the EtOAc $(4.55 \pm 0.13 \mathrm{mg} \mathrm{GAE} / \mathrm{g})$ and the PE $(28.44 \pm 2.85 \mathrm{mg} \mathrm{GAE} / \mathrm{g})$. The same result was obtained 
for content of flavonoids $(n-\mathrm{BuOH} 49.39 \pm 0.98 \mathrm{mg} \mathrm{QE} / \mathrm{g}$ EtOAc $8.72 \pm 1.08$, and PE $6.38 \pm$ $1.01 \mathrm{mg} \mathrm{QE} / \mathrm{g})$ (Table S1).

\subsection{Biological activity}

The results of phenolic and flavonoid contents were confirmed by the phytochemical investigation. Indeed, many phenolic and flavonoid compounds were isolated from the EtOAc and $n-\mathrm{BuOH}$ extracts. The antioxidant activity of the PE, EtOAc and $n-\mathrm{BuOH}$ extracts and some isolated compounds 5, 7-9 and 10-12 was evaluated by four methods DPPH, ABTS, CUPRAC, and reducing power assay; using ascorbic acid, BHA and BHT as positive control (Table S2).

The DPPH assay indicated a good activity for five tested compounds, in particular compounds 8 and 11 which afforded a potent activity $\left(\mathrm{IC}_{50} 8.16 \pm 0.27\right.$ and $18.81 \pm 0.17 \mu \mathrm{g} / \mathrm{mL}$, respectively) compared to ascorbic acid ( $\mathrm{IC}_{50} 13.94 \pm 2.81$ ), BHA ( $\mathrm{IC}_{50} 5.73 \pm 0.41 \mu \mathrm{g} / \mathrm{mL}$ ) and BHT ( $\left(\mathrm{IC}_{50} 22.32 \pm 1.19 \mu \mathrm{g} / \mathrm{mL}\right)$ as standards, while the $\mathrm{IC}_{50}$ for compounds 5 and $\mathbf{9}$ were not achieved at $100 \mu \mathrm{g} / \mathrm{mL}$ (Table S2). Compounds $\mathbf{8}$ and $\mathbf{1 1}$ showed also the highest activity in $\mathrm{ABTS}^{+}$. radical scavenging assay $\left(\mathrm{IC}_{50} 7.14 \pm 0.13\right.$ and $5.98 \pm 0.00 \mu \mathrm{g} / \mathrm{mL}$, respectively) compared to ascorbic acid ( $\left.\mathrm{IC}_{50} 1.74 \pm 0.10\right)$, BHA ( $\left.\mathrm{IC}_{50} 1.81 \pm 0.10 \mu \mathrm{g} / \mathrm{mL}\right)$, and BHT (IC 50 $1.29 \pm 0.30 \mu \mathrm{g} / \mathrm{mL}$ ), whereas good scavenging activity was observed for compounds $\mathbf{5}, \mathbf{7}, \mathbf{1 0}$ and 12 ( IC $_{50} 47.23 \pm 2.44,30.79 \pm 1.42,14.81 \pm 0.47$ and $17.09 \pm 0.64 \mu \mathrm{g} / \mathrm{mL}$, respectively). The CUPRAC assay was applied and all compounds revealing an excellent ability to reduce $\mathrm{Cu}^{+2}\left(\mathrm{IC}_{50}<0.78 \mu \mathrm{g} / \mathrm{mL}\right)$. In the reducing power assay, compounds $\mathbf{8}$ and 10-12 showed a good ability to reduce $\mathrm{Fe}^{+3}\left(\mathrm{IC}_{50} 10.76 \pm 0.80,27.45 \pm 1.16,14.18 \pm 0.25\right.$, and $19.83 \pm 0.60$ $\mu \mathrm{g} / \mathrm{mL}$, respectively), compared to ascorbic acid ( $\mathrm{IC}_{50} 6.37 \pm 0.42$ ), BHA ( $\mathrm{IC}_{50} 8.41 \pm 0.67$ $\mu \mathrm{g} / \mathrm{mL})$ and BHT $\left(\mathrm{IC}_{50}>100 \mu \mathrm{g} / \mathrm{mL}\right)($ Table S2).

Cholinesterases (ChEs) play a vital role in regulating cholinergic transmission. Inhibition of ChEs is thought to bean emerging and useful therapeutic target for neurodegenerative disorders through restoration of acetylcholine levels in the brain (e.g. Alzheimer's disease) (Bensouici et al. 2016). Since derivatives of quinoline alkaloids such as tacrine have promising ChE and BChE inhibitory effects (Cabral et al. 2012, Konrath et al. 2013, Mermer et al. 2018, Mishra et al. 2019), the unexplored quinoline alkaloid derivatives 1 and $\mathbf{2}$ and extracts in which they were detected, were evaluated for their acetylcholinesterase (AChE) and butyrylcholinesterase (BChE) inhibitory activity (S3). Galantamine was used as positif control Mishra et al 2019, (Table S3). The $n$-BuOH extract exhibited moderate ChE (IC 50 
$48.58 \pm 0.26 \mu \mathrm{g} / \mathrm{mL}$ ) and good $\mathrm{BChE}\left(\mathrm{IC}_{50} 22.85 \pm 2.15 \mu \mathrm{g} / \mathrm{mL}\right)$ inhibitory activities compared to galantamine $\left(\mathrm{IC}_{50}=6.27 \pm 1.15, \mathrm{AChE}\right.$ and $\left.34.75 \pm 1.99 \mu \mathrm{g} / \mathrm{mL}, \mathrm{BChE}\right)$. Compound 1 exhibited a significant AChE inhibitory activity $\left(\mathrm{IC}_{50}=18.48 \pm 0.33 \mu \mathrm{g} / \mathrm{mL}\right.$ ) and a potent BChE inhibitory activity $(9.66 \pm 0.16 \mu \mathrm{g} / \mathrm{mL})$, whereas compound 2 exhibited a moderate BChE inhibitory activity ( $\mathrm{IC}_{50} 37.49 \pm 1.61 \mu \mathrm{g} / \mathrm{mL}$ ).

\section{Conclusion}

In summary, one new alkaloid, pyrroloquinolone A (1), along with fifteen known compounds 2-16 were isolated and identified from the whole plant Atractylis cancellata L. The antioxidant activity, evaluated by DPPH, ABTS, CUPRAC, and reducing power methods, showed that compounds $\mathbf{8}$ and $\mathbf{1 1}$ possesses good antioxidant activity. Furthermore, the $n$ $\mathrm{BuOH}$ extract, pyrroloquinolone $\mathrm{A}$, and compound 2 showed good $\mathrm{AChE}$ and $\mathrm{BChE}$ inhibitory activities. This study reports for the first time the occurrence of alkaloids in the Atractylis genus.

\section{Supplementary material}

General experimental methods, UV, HR-ESI-MS, ${ }^{1} \mathrm{H}$ and ${ }^{13} \mathrm{C}$ NMR, COSY, HSQC and HMBC spectra of compound $\mathbf{1}$ are available online.

\section{Acknowledgements}

The authors are grateful to the Ministry of Higher Education and Scientific Research of Algeria for PRFU Project (B00L01UN050120180001), CRBt (Constantine-Algeria), Conseil Regional Champagne Ardenne, Conseil General de la Marne, Ministry of Higher Education and Research (MESR) France and EU-program FEDER to the PlAneT CPER project.

\section{Disclosure statement}

No potential conflict of interest was reported by the authors.

\section{Statistical analysis}

All data on both chemical analysis and bioassays activity tests were the average of triplicate analyses. The data were recorded as mean values \pm standard deviation. The $\mathrm{IC}_{50}$ values were calculated by linear regression analysis, and one-way analysis of variance ANOVA to detect significant differences $(\mathrm{p}<0.05)$ by Tukey using XLSTAT. 


\section{References}

Bensouici C, Kabouche A, Karioti A, Ozturk M, Duru ME, Bilia AR, Kabouche Z. 2016. Compounds from Sedum caeruleum with antioxidant, anticholinesterase, and antibacterial activities. Pharm Biol. 54: 174-179.

Cabral RS, Sartori MC, Cordeiro I, Queiroga CL, Eberlin MN, Lago JHG, Moreno PRH, Young MCM. 2012. Anticholinesterase activity evaluation of alkaloids and coumarin from stems of Conchocarpus fontanesianus. Braz J Pharmacog. 22(2): 374-380.

Chabani S, Haba H, Lavaud C, Benkhaled M, Harakat D. 2013. Flavonoid glycosides and triterpenoids from Atractylis flava. Phytochem Lett. 6: 9-13.

Chabani S, Lavaud C, Benkhaled M, Harakat D, Long C, Haba H. 2016a. Three new oleanane-type triterpene saponins from Atractylis flava. Phytochem Lett. 15: 88-93.

Chabani S, Haba H, Long C, Benkhaled M. 2016b. Chemical composition of medicinal plant Atractylis serratuloides. Ind Crops Prod. 88: 91-95.

Chang SW, Kim KH, Lee IK, Choi SU, Ryu SY, Lee KR.2009. Phytochemical constituents of Bistorta manshuriensis. Nat. Prod. Sci. 15: 234-240.

Chaturvedula VSP, Prakash I. 2012. Isolation of Stigmasterol and $\beta$-Sitosterol from the dichloromethane extract of Rubus suavissimus. Int Curr Pharm J. 1: 239-242.

Daniele C, Dahamna S, Firuzi O, Sekfali N, Saso L, Mazzanti G. 2005. Atractylis gummifera L. poisoning: an ethnopharmacological review. J Ethnopharmacol. 97: 175-181.

El Rhaffari L, Zaid A. 2002. Pratique de la phytothérapie dans le sud-est du Maroc (Tafilalet). In : Des sources du savoir aux médicaments du futur ; Ed : IRD, Marseille, France, pp: 293-318.

Funk VA, Bayer RJ, Keeley S, Chan R, Watson L, Gemeinholzer B, Schilling E, Panero JL, Baldwin BG, Garcia-Jacas N, Susanna A, Jansen RK. 2005. Everywhere but Antarctica: using a superthree to understand the diversity and distribution of the Compositae. Biol. Skr. 55: 343-374.

Ghasemi S, Lorigooini Z, Wibowo J, Amini-khoei H. 2018. Tricin isolated from Allium atroviolaceum potentiated the effect of docetaxel on PC3 cell proliferation: role of miR21. Nat. Prod. Res. 15: 1-4.

Konrath EL, Ortega MG, De Loreto Bordignon S, Apel MA, Henriques AT, Cabrera JL. 2013. Alkaloid profiling and anticholinesterase activity of South American Lycopodiaceae species. J Enzyme Inhib Med Chem. 28: 218-222. 
Khaligh P, Salehi P, Farimani MM, Ali-Asgari S, Esmaeili MA, Ebrahimi SN. 2016. Bioactive compounds from Smilax excelsa L. J Iran Chem. Soc. 13: 1055-1059.

Larrey D, Pageaux GP. 1995. Hepatotoxicity of herbal remedies and mushrooms. Semin Liver Dis. 15: $183-188$.

Liu H, Mou Y, Zhao J, Wang J, Zhou L, Wang M, Wang D, Han J, Yu Z, Yang F. 2010. Flavonoids from Halostachys caspica and their antimicrobial and antioxidant activities. Molecules. 15: 7933-7945.

Melakhessou MA, Benkiki N, Marref S, Bouzidi S. 2018. Anti-inflammatory, anti-pyretic and acute toxicity effects of $n$-butanol extract of Atractylis flava Desf. in rats. Pharmacogn. J. 10: 763-767.

Mermer A, Demirbas N, Sirin Y, Uslu H, Ozdemir Z, Demirbas A. 2018. Conventional and microwave prompted synthesis, antioxidant, anticholinesterase activity screening and molecular docking studies of new quinolone-triazole hybrids. Bioorganic Chemistry. 78: $236-248$.

Mishra P, Kumar A, Panda G. 2019. Anti-cholinesterase hybrids as multi-target-directed ligands against Alzheimer's disease (1998-2018). Bioorg Med Chem. 27:895-930.

Nayar MNS, Sutar CV, Bhan MK. 1971. Alkaloids of the bark of Hesperethusa crenulatta. Phytochemestry 10: 2843-2844.

Peshin T, Kar HK. 2017. Isolation and characterization of $\beta$-sitosterol-3- $O$ - $\beta$-D-glucoside from the extract of the flowers of Viola odorata. Br J Pharm Res. 16: 1-8.

Quezel P, Santa S.1963. New Flora of Algeria and the Southern Desert Regions, Tome 2; C.N.R.S., Paris: 998-1002.

Sadek EG, Metwally MA, Mpango GB. 1998. Triterpenes from Atractylis carduus L. Boll. Chim. Farm. 137: 249-250.

Seebacher W, Simic N, Weis R, Saf R, Kunert O. 2003. Complete assignments of ${ }^{1} \mathrm{H}$ and ${ }^{13} \mathrm{C}$

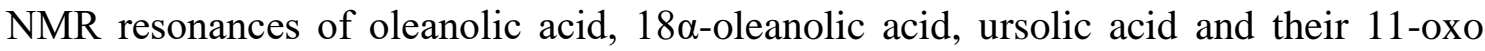
derivatives. Magn Reson Chem. 41: 636-638.

Silva ATM, Magalhães CG, Duarte LP, Mussel WN, Ruiz ALTG, Shiozawa L, Carvalho JE, Trindade IC, Vieira Filho SA. 2017. Lupeol and its esters: NMR, powder XRD data and in vitro evaluation of cancer cell growth. Braz J Pharm Sci. 53: 1-10.

Szeleszczuk L, Pisklak DM, Zielińska-Pisklak M, Wawer I. 2017. Spectroscopic and structural studies of the diosmin monohydrate and anhydrous diosmin. Int. J. Pharm. 529: 193-199. 
Tim CTH, Keith J. 1997. A synthesis of the tricyclic pyrroloquinoline core of martinelline. Tetrahedron. 53: 8287-8297.

Bammou M, Daoudi A, Sellam K, El-Rhaffari E, Ibijbijen J, Nassiri L. 2015. Ethnobotanical Survey of Asteraceae Family used in Meknes-Tafilalet Region (Morocco) International Journal of Innovation and Applied Studies 13, 789-815. 


\section{SUPPLEMENTARY DATA}

\section{Pyrroloquinolone A, a new alkaloid and other phytochemicals from}

Atractylis cancellata $\mathbf{L}$. with antioxidant and anticholinesterase activities

Mohamed Ibrahim Badaoui ${ }^{\mathrm{a}}$, Abdulmagid Alabdul Magid ${ }^{\mathrm{b}}$, Mohammed

Benkhaled $^{\text {a }}$, Chawki Bensouicic ${ }^{\mathrm{c}}$, Dominique Harakat ${ }^{\mathrm{d}}$, Laurence Voutquenne-

Nazabadioko ${ }^{\mathrm{b}}$, and Hamada Haba ${ }^{\mathrm{a}, *}$

${ }^{a}$ Laboratoire de Chimie et Chimie de l'Environnement (LCCE), Département de Chimie,

Faculté des Sciences de la Matière, Université de Batna-1 05000, Algeria

${ }^{b}$ Equpie Chimie des Substances Naturelles, Institut de Chimie Moléculaire de Reims (ICMR-

UMR CNRS 7312), Campus Sciences, Bât. 18, BP 1039, 51687, Reims Cedex 2, France

${ }^{c}$ Centre de Recherche en Biotechnologie, Ali Mendjli, UV 03, BP E73, Constantine, Algeria.

${ }^{d}$ Service Commun d'Analyses, ICMR-UMR CNRS 7312, Bât. 18 B.P. 1039, 51687, Reims,

Cedex 2, France

* Corresponding author: Hamada Haba Tel: +213 333190 15; Fax: +213 333190 15; E-mail address: haba.hamada@yahoo.fr; hamada.haba@univ-batna.dz 


\begin{abstract}
A new alkaloid pyrroloquinolone A (1), along with fifteen known compounds 2-16 were isolated from the petroleum ether, EtOAc and $n-\mathrm{BuOH}$ extracts of the whole plant Atractylis cancellata $\mathrm{L}$. Their structures were elucidated on the basis of extensive spectroscopic analysis including 1D- and 2D-NMR and HR-ESI-MS techniques. This is the first report of alkaloids in the genus Atractylis. Some of the isolated compounds and extracts were evaluated for their antioxidant potential (scavenging activity of DPPH and ABTS radicals, and reducing $\mathrm{Fe}^{+3}$ and $\mathrm{Cu}^{+2}$ power assays) and acetylcholinesterase and butyrylcholinesterase inhibitory activities. Compounds $\mathbf{8}$ and $\mathbf{1 1}$ showed good antioxidant capacity compared to ascorbic acid, BHA, and BHT used as standards, whereas compounds $\mathbf{1}$ and $\mathbf{2}$ exhibited good anticholinesterase activities compared to galantamine used as standard.
\end{abstract}

Keywords: Asteraceae, Atractylis cancellata L., Pyrroloquinolone A, NMR, Antioxidant activity, Anticholinesterase activity 


\section{Experimental}

\section{General experimental procedures}

1D- and 2D-NMR spectra were carried out in $\mathrm{CDCl}_{3}, \mathrm{CH}_{3} \mathrm{OH}-d_{4}$, or DMSO- $d_{6}$ on Bruker Avance DRX III 500 instrument using standard Bruker microprograms (Karlsruhe, Germany). ESI-MS experiments were performed using a Micromass Q-TOF micro-instrument (Manchester, UK). TLC were realized on pre-coated silica-gel $60 \mathrm{~F}_{254}$ Merck and were visualized under UV light at 254 and $366 \mathrm{~nm}$ and by spraying the dried plates with 50\% $\mathrm{H}_{2} \mathrm{SO}_{4}$, followed by heating. Flash chromatography was performed on a Grace Reveleris system equipped with dual UV and ELSD detection using Grace cartridges (Silica gel or RP$\mathrm{C} 18$ ), and the effluents were monitored at 205 and $254 \mathrm{~nm}$. The Medium pressure liquid chromatography (MPLC) was employed using a Buchi pump system coupled (Bushi, France), with $\mathrm{C}_{18}$-silica gel packed glass column $(15 \times 230$ and $26 \times 460 \mathrm{~mm})$. Semi-prep. HPLC was performed on a Dionex apparatus equipped with an ASI-100 autosampler, an Ultimate 3000 pump, a diode array detector UVD 340S and a Chromeleon software (ThermoFisher Scientific, France). RP-C 18 column (Phenomenex $250-15 \mathrm{~mm}$, Luna $5 \mathrm{~m}$ ) was used for semi preparative HPLC with a binary gradient eluent $\left(\mathrm{H}_{2} \mathrm{O}\right.$ pH 2.4 with TFA; MeCN) and a flow rate of $5 \mathrm{~mL} / \mathrm{min}$ (interchim, France); the chromatogram was monitored at 205, 254, 300, and $360 \mathrm{~nm}$.

The bioactivity measurements were carried out at National Center of biotechnology Research (Algeria) on a 96-well microplate reader, Perkin Elmer Multimode Plate Reader EnSpire (Perkin Elmer, France). Folin-ciocalteu's reagent (FCR), 1,1-diphenyl-2-picrylhydrazyl (DPPH), butylated hydroxylanisole (BHA), butylated hydroxyltoluene (BHT), $\alpha$-tocopherol, ascorbic acid, neocuproine, 2,2'-azinobis(3-ethyl-benzothiazoline-6-suphonic acid) diammonium salt (ABTS), trichloroacetic acid (TCA), potassium ferricyanide, ammonium acetate, trichloro- acetic acid, potassium acetate, aluminum nitrate and 5,5'-dithiobis(2nitrobenzoic acid) (DTNB), potassium ferricyanide, were obtained from Sigma Chemical Co. (Sigma-Aldrich GmbH, Stern-heim, Germany). Sodium carbonate, aluminium nitrate, iron (III) chloride, iron (II) chloride, copper (II) chloride, potassium persulfate, potassium acetate, acetylcholinesterase (AChE), butyrylcholinesterase (BChE), acetylcholine iodide, butylcholine iodide were obtained from Biochem Chemopharma (Biochem Chemopharma, France). All other chemicals and solvents were of analytical grade.

\section{Plant material}


The whole plant Atractylis cancellata L. was collected in May 2015 in Djerma from semi-arid region of Batna (North eastern of Algeria) by Prof. Hamada Haba. It was authentified by Prof. Bachir Oudjehiche from the Agronomic Institute of the University of Batna-1 (Algeria). A voucher specimen (846/LCCE) has been deposited at the Faculty of Sciences of Matter, University of Batna-1, Algeria.

\section{Preparation of plant extracts}

The dry powdered whole plant of $A$. cancellata $(1.2 \mathrm{~kg})$ was macerated in EtOH $70 \%(2 \times 12$ $\mathrm{L}, 48 \mathrm{~h}$ ) at room temperature, and then concentrated under low pressure to remove EtOH. The aqueous residue was diluted with $500 \mathrm{~mL}$ of $\mathrm{H}_{2} \mathrm{O}$, and successively extracted with Petroleum Ether $(3 \times 300 \mathrm{~mL})$, ethyl acetate $(3 \times 300 \mathrm{~mL})$, and $n$-butanol $(3 \times 300 \mathrm{~mL})$. The obtained organic phases were evaporated to give $13.4 \mathrm{~g}$ of PE, $10 \mathrm{~g}$ of EtOAc and $16.8 \mathrm{~g}$ of $n$-BuOH extracts. All the extracts were evaporated at $45{ }^{\circ} \mathrm{C}$, under low pressure using rotary evaporator and the extracts and their fractions were stored in darkness at room temperature before fractionation and purification.

\section{Chemical screening of plant extracts}

Total phenolic content (TPC) was measured for the obtained extracts (PE, EtOAc and $n$ $\mathrm{BuOH})$ using the method of Muller et al. (2010), for the calibration, the gallic acid solution at various concentrations was used and the result was given as gallic acid equivalents ( $\mu \mathrm{g}$ GAE/mg extract).

The measurement of total flavonoids content (TFC) was carried out by the procedure of Topçu et al.(2007), the TFC of extracts was expressed as quercetin equivalents ( $\mu \mathrm{g} \mathrm{QE} / \mathrm{mg}$ extract), with quercetin for calibration.

\section{Isolation and purification}

The PE extract ( $5 \mathrm{~g}$ ) was fractionated by Vacuum Liquid Chromatography (VLC) over silica gel eluted with PE-EtOAc (1:0 - 0:1), to give 9 fractions (P1-P9). Fraction P3 (725 mg) was applied to silica Column Chromatography (CC) gel and eluted with PE-EtOAc (1:0 - 0:1) to afford compounds 15 (172 mg), $13(13 \mathrm{mg})$ and $14(7 \mathrm{mg})$.

The EtOAc extract ( $7 \mathrm{~g}$ ) was subjected to silica gel VLC eluted with PE-EtOAc-MeOH (1:0:0 - 0:1:0 - 0:0:1) to result 13 fractions (Ac1-Ac13). Ac5 (549 mg) was separated over silica gel CC (PE-EtOAc 1:0 - 0:1) and 14 sub-fractions were collected (Ac5-A to Ac5-N). The subfraction Ac5-J was fractionated over polyamide CC (Toluene-MeOH 1:0 - 0:1) in order to 
obtain compounds 4 (1.3 mg) and 6 (3 mg). The fractions Ac6-Ac8 were combined (2.7 g) and subjected to silica gel $\mathrm{CC}$ eluted with $\mathrm{CH}_{2} \mathrm{Cl}_{2}$-Acetone-MeOH (1:0:0 - 0:1:0 - 0:0:1) to give 8 sub-fractions (Ac6-A to Ac6-H). The sub-fraction Ac6-C contained the compound 3 (3 mg). Fraction Ac9 (1.1 g) was fractionated by silica gel CC (PE-EtOAc-MeOH 1:0:0 - 0:1:0 0:0:1) to afford 15 sub-fractions (Ac9-A to Ac9-O), then Ac9-G (85 mg) was purified with silica gel $\mathrm{CC}\left(\mathrm{CHCl}_{3}-\mathrm{MeOH}\right.$ 1:0 - 90:10) to furnish compound 16 (5 mg). Fractions Ac10Ac11 were combined (2.8 g) and subjected to silica gel $\mathrm{CC}\left(\mathrm{CHCl}_{3}-\mathrm{MeOH}\right.$ 1:0 - 0:1) to give 15 sub-fractions (Ac10-A to Ac10-O). Ac10-H (285 mg) was purified with polyamide CC (Toluene-MeOH 1:0 - 0:1) to obtain compound 5 (7 mg).

The $n$-BuOH extract (13.4g) was subjected to VLC over RP-18 eluted with $\mathrm{MeOH}-\mathrm{H}_{2} \mathrm{O}$ (25:75 - 1:0) to afford 4 fractions (Bu1-Bu4). Bu2 (2.7 g) was purified by preparative HPLC using $\mathrm{MeCN}$ (isocratic elution $10 \%$ for $30 \mathrm{~min}, 10 \% \rightarrow 100 \%$ in $20 \mathrm{~min}$ ) to yield 21 subfractions (Bu2-A to Bu2-U). Compound 8 (42 mg) was precipitated in $\mathrm{MeCN}$ of sub-fraction Bu2-Q. Sub-fraction Bu2-H (80 mg) was purified by semi-prep. HPLC (10\% MeCN, isocratic elution) to give compound $\mathbf{1 1}\left(\mathrm{R}_{\mathrm{t}} 15.2 \mathrm{~min}, 24 \mathrm{mg}\right)$. Sub-fraction Bu2-K (115 mg) was purified by semi-prep. HPLC (isocratic elution $10 \% \mathrm{MeCN}$ ) to afford compound $\mathbf{1 0}\left(\mathrm{R}_{\mathrm{t}} 25.5\right.$ min, $25 \mathrm{mg}$ ). Fraction Bu2-P (160 mg) was fractionated by flash chromatography over silica gel eluted with $\mathrm{CH}_{2} \mathrm{Cl}_{2}-\mathrm{MeOH}-\mathrm{H}_{2} \mathrm{O}$ (1:0:0 - 70:30:0 - 70:30:5) to give ten sub-fractions (Bu2P1-Bu2-P10). Bu2-P4 (14 mg) was purified by semi-prep. HPLC $(14 \rightarrow 20 \% \mathrm{MeCN}$ in 20 min) to yield compound $12\left(\mathrm{R}_{\mathrm{t}} 11.0 \mathrm{~min}, 3 \mathrm{mg}\right)$. The combined fractions Bu3 and $\mathrm{Bu} 4(2.2 \mathrm{~g})$ were applied to flash chromatography over silica gel, eluted with $\mathrm{CH}_{2} \mathrm{Cl}_{2}-\mathrm{MeOH}-\mathrm{H}_{2} \mathrm{O}$ (90:10:0 - 70:30:0 - 70:30:5) affording 22 sub-fractions (Bu3-A-V). Compound 9 (3 mg) was precipitated in $\mathrm{MeOH}$ solution of sub-fraction Bu3-G (99 mg). Bu3-P (300 mg) was subjected to prep. HPLC ( $15 \% \mathrm{MeCN}$ in $30 \mathrm{~min}$, then $15 \% \rightarrow 100 \% \mathrm{MeCN}$ in $20 \mathrm{~min}$ ) to give $22 \mathrm{sub}-$ fractions (Bu3-P1 to Bu3-P22). The fractions Bu3-P2 (9 mg), Bu3-P10 (14 mg) and Bu3-P1519 -t $(33 \mathrm{mg}$ ) were purified separately by semi-prep. HPLC $(10 \rightarrow 20 \% \mathrm{MeCN}$ in $20 \mathrm{~min})$ to give compounds $2\left(R_{t} 12.5,2 \mathrm{mg}\right), 7\left(R_{t} 10.0 \mathrm{~min}, 3 \mathrm{mg}\right)$, and $1\left(R_{t} 7.7 \mathrm{~min}, 2 \mathrm{mg}\right)$, respectively.

\section{Biological studies}

In order to evaluate the antioxidant activity, we have applied four different methods: DPPH free radical scavenging, ABTS, CUPRAC and reducing power assays. The ascorbic acid, BHA and BHT were used as antioxidant standards. The radical scavenging activity (\%) or reducing capacity ratio $(\%)$ were is calculated by the following formula: $100 \times\left[\mathrm{A}_{0}-\mathrm{A} / \mathrm{A}_{0}\right]$, 
where $\mathrm{A}_{0}$ and $\mathrm{A}$ are the absorbances of the system in the absence and presence of sample, respectively. The $\mathrm{IC}_{50}$ values were interpolated from a linear regression plot of sample concentration against scavenging effect/or reducing capacity in percentage.

\section{DPPH free radical scavenging assay}

The free radical scavenging assay was evaluated by the DPPH assay described by Blois (1958) with a slight modification. Briefly, $180 \mu \mathrm{L}$ of DPPH solution $(0.4 \mathrm{mM})$ was added to $20 \mu \mathrm{L}$ of samples dissolved in $\mathrm{MeOH}$, at different concentrations; a control containing $40 \mu \mathrm{L}$ of $\mathrm{MeOH}$ with $160 \mu \mathrm{L}$ of DPPH solution was used, after 30 min in darkness the absorbance was measured at $517 \mathrm{~nm}$.

\section{ABTS cation radical decolorization assay}

The method of Re et al. (1999) was used with slight modification to assess the capacity of extracts and isolated compounds to scavenge the $\mathrm{ABTS}^{++}$radical. The $\mathrm{ABTS}^{+}$radical-cation is regenerated by adding $2.45 \mathrm{mM}$ of potassium persulfate to an aqueous solution of $7 \mathrm{mM}$ ABTS which is stored in the dark at room temperature for 12 hours. To each well, in 96- well plate, $180 \mu \mathrm{L}$ of ABTS $^{+}$solution was added to $20 \mu \mathrm{L}$ of sample solution at different concentrations. After $10 \mathrm{~min}$, the absorbance was measured at $734 \mathrm{~nm}$.

\section{Cupric reducing antioxidant capacity (CUPRAC) assay}

The cupric-reducing antioxidant capacity was evaluated according to the method of Apak et al. (2004), with slight modifications. To each well, in a 96-well plate, $50 \mu \mathrm{L} 10 \mathrm{mM}$ copper (II) chloride, $50 \mu \mathrm{L} 7.5 \mathrm{mM}$ neocuproine and $60 \mu \mathrm{L}$ ammonium acetate buffer (1 M, pH 7.0) solutions were added. $40 \mu \mathrm{L}$ of the sample at different concentrations was added to the initial mixture. After $60 \mathrm{~min}$, the absorbance was measured at $450 \mathrm{~nm}$.

\section{Reducing power assay}

The reducing power of the tested compounds was determined according to the method of Bouratoua et al. (2017). In order to evaluate the reducing power activity, $10 \mu 1$ of serial diluted sample was added into a 96 well round-bottomed plate. Following this, $40 \mu \mathrm{L}$ of 0.2 $\mathrm{M}$ phosphate buffer ( $\mathrm{pH} 6.6$ ) and $50 \mu \mathrm{L}$ of potassium ferricyanide (1\%), were added to each well and the plate was incubated at $50{ }^{\circ} \mathrm{C}$ for $20 \mathrm{~min}$. Finally, $50 \mu \mathrm{L}$ of TCA (10\%) and distilled water $(40 \mu \mathrm{L})$ and $10 \mu \mathrm{L}$ of ferric chloride $(0.1 \%)$, were added into each well in order to measure the reducing power activity. Then, the absorbance was measured in a microplate reader at $700 \mathrm{~nm}$. Higher absorbance of the reaction mixture indicates greater reducing power. Anticholinesterase activity 
Acetylcholinesterase (AChE) and butyrylcholinesterase (BChE) inhibitory activity was measured using the spectrophotometric method developed by Ellman et al. (1961). Briefly, $150 \mu \mathrm{L}$ of $100 \mathrm{mM}$ sodium phosphate buffer ( $\mathrm{pH}$ 8.0), $10 \mu \mathrm{L}$ of sample solution dissolved in methanol at different concentrations and $20 \mu \mathrm{L} \mathrm{AChE}\left(5.32 \times 10^{-3} \mathrm{U}\right)$ or $\mathrm{BChE}\left(6.85 \times 10^{-3} \mathrm{U}\right)$ solution were mixed and incubated for $15 \mathrm{~min}$ at $25^{\circ} \mathrm{C}$; then $10 \mu \mathrm{L}$ of $0.5 \mathrm{mM}$ DTNB [5,5'dithio-bis(2-nitrobenzoic) acid] was added. The reaction was then initiated by the addition of $10 \mu \mathrm{L}$ of acetylthiocholine iodide $(0.71 \mathrm{mM})$ or butyrylthiocholine chloride $(0.2 \mathrm{mM})$. The hydrolysis of these substrates was monitored spectrophotometrically by the formation of yellow 5-thio-2-nitrobenzoate anion, as the result of the reaction of DTNB with thiocholine, released by the enzymatic hydrolysis of acetylthiocholine iodide or butyrylthiocholine chloride, respectively, at a wavelength of $412 \mathrm{~nm}$, every $5 \mathrm{~min}$ for $15 \mathrm{~min}$, using a 96-well microplate reader (Perkin Elmer Multimode Plate Reader EnSpire, USA) in triplicate experiments. Galantamine was used as reference compound. The inhibition of AChE or BChE (\%) was calculated using the formula: $(\mathrm{E}-\mathrm{S}) / \mathrm{E} \times 100$, where $\mathrm{E}$ is the activity of enzyme without test sample, and $\mathrm{S}$ is the activity of enzyme with test sample. The $\mathrm{IC}_{50}$ values were interpolated from a linear regression plot of extracts and compounds concentration against inhibition effect in percentage.

\section{References}

Apak R, Guclu K, Ozyurek M, Karademir SE. 2004. Novel total antioxidant capacity index for dietary polyphenols and vitamins $\mathrm{C}$ and $\mathrm{E}$, Using their cupric ion reducing capability in the presence of neocuproine: CUPRAC Method. J Agric Food Chem. 52: 7970-7981.

Blois MS. 1958. Antioxidant determinations by the use of a stable Free Radical. Nature. 181: 1119-1200.

Bouratoua A, Khalfallah A, Bensouici B, Kabouche Z, Alabdul Magid A, Harakat D, Voutquenne-Nazabadioko L, Kabouche A. 2018. Chemical composition and antioxidant activity of aerial parts of Ferula longipes Coss. ex Bonnier and Maury. Nat prod res. 32: 1873-1880.

Ellman GL, Courtney KD, Andres V, Featherston RM. 1961. A new and rapid colorimetric determination of acetylcholinesterase activity. Biochem. Pharmacol. 7(2): 88-95.

Müller L, Gnoyke S, Popken AM, Böhm V. 2010. Antioxidant capacity and related parameters of different fruit formulations. LWT - Food Sc Technol. 43: 992-999. 
Re R, Pellegrini N, Proteggente A, Pannala A, Yang M, Rice-Evans C. 1999. Antioxidant activity applying an improved ABTS radical cationdecolorizationassay. Free Radical Bio. Med. 26: 1231-1237.

Topçu G, Ay A, Bilici A, Sarıkürkcü C, Öztürk M, Ulubelen A. 2007. A new flavone from antioxidant extracts of Pistacia terebinthus. Food Chem. 103: 816-822. 
Table S1. Phenolic and flavonoid contents in A. cancellata extracts

\begin{tabular}{ccc}
\hline Extracts & TPC $\left(\mathbf{m g ~ G A E}^{\mathrm{x}} / \mathbf{g}\right)$ & TFC $\left(\mathbf{m g ~ Q E} \mathbf{E}^{\mathrm{y}} / \mathbf{g}\right)$ \\
\hline PE & $28.44 \pm 2.85^{\mathrm{a}}$ & $6.38 \pm 1.01^{\mathrm{b}}$ \\
EtOAc & $4.55 \pm 0.13^{\mathrm{b}}$ & $8.72 \pm 1.08^{\mathrm{b}}$ \\
$\boldsymbol{n}$-BuOH & $53.20 \pm 1.21^{\mathrm{c}}$ & $49.39 \pm 0.98^{\mathrm{a}}$ \\
\hline
\end{tabular}

${ }^{\mathrm{x}}$ Gallic acid equivalent, ${ }^{\mathrm{y}}$ quercetin equivalent

Table S2. Antioxidant activity of A. cancellata extracts and some isolated compounds by the DPPH, ABTS, CUPRAC and reducing power assays

\begin{tabular}{|c|c|c|c|c|}
\hline \multirow{3}{*}{ Extracts/Compounds } & \multicolumn{4}{|c|}{ Antioxidant Activities } \\
\hline & DPPH assay & ABTS assay & CUPRAC assay & Reducing Power assay \\
\hline & \multicolumn{2}{|c|}{$\mathrm{IC}_{50}(\mu \mathrm{g} / \mathrm{mL})$} & \multicolumn{2}{|c|}{$\mathrm{IC}_{50}(\mu \mathrm{g} / \mathrm{mL})$} \\
\hline PE extract & $>100$ & $>100$ & $194.17 \pm 2.36^{\mathrm{a}}$ & $>100$ \\
\hline EtOAc extract & $>100$ & $>100$ & $148.56 \pm 0.28^{b}$ & $>100$ \\
\hline n-BuOH extract & $60.55 \pm 2.18^{\mathrm{a}}$ & $36.58 \pm 2.41^{\mathrm{b}}$ & $36.59 \pm 0.76^{c}$ & $49.25 \pm 0.08^{\mathrm{a}}$ \\
\hline 5 & $>100$ & $47.23 \pm 2.44^{\mathrm{a}}$ & $0.58 \pm 0.23^{g}$ & $>50$ \\
\hline 7 & $57.91 \pm 1.83^{\mathrm{a}}$ & $30.79 \pm 1.42^{c}$ & $0.73 \pm 0.48^{\mathrm{g}}$ & $>50$ \\
\hline 8 & $8.16 \pm 0.27^{\mathrm{e}}$ & $7.14 \pm 0.13^{\mathrm{e}}$ & $0.73 \pm 0.35^{\mathrm{g}}$ & $10.76 \pm 0.80^{\mathrm{e}}$ \\
\hline 9 & $>100$ & NT & $0.60 \pm 0.39^{g}$ & $>50$ \\
\hline 10 & $25.80 \pm 0.39^{\mathrm{b}}$ & $14.81 \pm 0.47^{\mathrm{d}}$ & $0.71 \pm 0.60^{\mathrm{g}}$ & $27.45 \pm 1.16^{\mathrm{b}}$ \\
\hline 11 & $18.81 \pm 0.17^{\mathrm{c}}$ & $5.98 \pm 0.00^{\mathrm{e}}$ & $0.70 \pm 0.20^{\mathrm{g}}$ & $14.18 \pm 0.25^{\mathrm{d}}$ \\
\hline 12 & $25.01 \pm 0.55^{\mathrm{b}}$ & $17.09 \pm 0.64^{\mathrm{e}}$ & $0.71 \pm 0.57^{\mathrm{g}}$ & $19.83 \pm 0.60^{c}$ \\
\hline BHA & $5.73 \pm 0.41^{\mathrm{e}}$ & $1.81 \pm 0.10^{\mathrm{f}}$ & $3.64 \pm 0.19^{f, g}$ & $8.41 \pm 0.67^{\mathrm{e}}$ \\
\hline BHT & $22.32 \pm 1.19^{\mathrm{b}, \mathrm{c}}$ & $1.29 \pm 0.30^{\mathrm{f}}$ & $9.62 \pm 0.87^{\mathrm{e}, \mathrm{g}}$ & $>100$ \\
\hline Ascorbic acid & $13.94 \pm 2.81^{\mathrm{d}}$ & $1.74 \pm 0.10^{\mathrm{f}}$ & $12.43 \pm 0.09^{\mathrm{d}}$ & $6.37 \pm 0.42^{g}$ \\
\hline
\end{tabular}

$\mathrm{IC}_{50}$ values are defined as the concentration of $50 \%$ inhibition percentages and calculated by linear regression analysis and expressed as Mean $\pm \mathrm{SD}(\mathrm{n}=3)$. The $\mathrm{IC}_{50}$ values with different superscripts $(\mathrm{a}, \mathrm{b}, \mathrm{c}, \ldots)$ in the same column are significantly different ( $\mathrm{p}$ 0.05). BHA: Butylatedhydroxyanisole, BHT: Butylatedhydroxytoluene, NA: not tested. 
Table S3. Acetylcholinesterase (AChE) and butyrylcholinesterase (BChE) inhibitory activities of various extracts and isolated alkaloids of A. cancellata

\begin{tabular}{ccc}
\hline & \multicolumn{2}{c}{ Anticholinesterase activity } \\
Extract/compound & AChE & BChE \\
\cline { 2 - 3 } PE extract & $>200$ & $>200$ \\
EtOAc extract & $>200$ & $>200$ \\
$\boldsymbol{n}$-BuOH extract & $48.58 \pm 0.26^{\mathrm{a}}(\mu \mathrm{g} / \mathrm{mL})$ & $22.85 \pm 2.15^{\mathrm{b}}$ \\
$\mathbf{1}$ & $18.48 \pm 0.33^{\mathrm{b}}$ & $9.66 \pm 0.16^{\mathrm{c}}$ \\
Galantamine & $>50$ & $37.49 \pm 1.61 \mathrm{a}$ \\
\end{tabular}

IC50 values is defined as the concentration of 50\% inhibition percentages and calculated by linerar regression analysis and expessed as mean \pm SD ( $n=3)$. The IC50 values with different superscripts $(a, b, c \ldots)$ in the same column are significantly different $(\mathrm{p}<0.05)$.

Table S4. NMR spectroscopic data of compound 1 in $\mathrm{MeOH}-d_{4}$ (in ppm and $J$ in $\mathrm{Hz}$ )

\begin{tabular}{ccc}
\hline \multirow{2}{*}{ position } & \multicolumn{2}{c}{$\mathbf{1}$} \\
\cline { 2 - 3 } & $\delta_{\mathrm{C}}$ & $\delta_{\mathrm{H}}$ \\
\hline 2 & 125.1 & $7.46(1 \mathrm{H}, \mathrm{d}, 3.1 \mathrm{~Hz})$ \\
3 & 103.9 & $7.12(1 \mathrm{H}, \mathrm{d}, 3.1 \mathrm{~Hz})$ \\
$3 \mathrm{a}$ & 108.6 & - \\
4 & 152.4 & - \\
N-Me & 33.1 & $4.02(3 \mathrm{H}, \mathrm{s})$ \\
$6 \mathrm{a}$ & 135.1 & - \\
6 & 116.9 & $8.01(1 \mathrm{H}, \mathrm{d}, 8.7 \mathrm{~Hz})$ \\
7 & 129.0 & $7.61(1 \mathrm{H}, \mathrm{t}, 7.6 \mathrm{~Hz})$ \\
8 & 124.9 & $8.24(1 \mathrm{H}, \mathrm{brd}, 8.0 \mathrm{~Hz})$ \\
9 & 121.5 & - \\
$9 \mathrm{a}$ & 115.1 & - \\
$9 \mathrm{~b}$ & 134.8 & $(1 \mathrm{H}, \mathrm{ddd}, 8.7,7.6,1.3 \mathrm{~Hz})$ \\
\hline
\end{tabular}

